\title{
Amyloid Formation in Response to $\beta$ Cell Stress Occurs In Vitro, but Not In Vivo, in Islets of Transgenic Mice Expressing Human Islet Amyloid Polypeptide
}

\author{
Gunilla Westermark, ${ }^{*}$ Michelle Benig Arora, ${ }^{\dagger}$ Niles Fox, ${ }^{\neq}$ \\ Raymond Carroll, ${ }^{\S}$ Shu Jin Chan, $\$$ \\ Donald F. Steiner ${ }^{\S}$ \\ *Department of Pathology, Faculty of Health Sciences, Linköping \\ University, Linköping, Sweden \\ ${ }^{+}$Department of Biochemistry, College of Medicine West, University of \\ Illinois, Chicago, Illinois, U.S.A. \\ ${ }^{\ddagger}$ Lilly Research Laboratories, Lilly Corporate Center, Indianapolis, \\ Indiana, U.S.A. \\ ${ }^{\S}$ Department of Biochemistry and Molecular Biology and the Howard \\ Hughes Medical Institute, University of Chicago, Chicago, Illinois, U.S.A.
}

\begin{abstract}
Background: Human, but not mouse, islet amyloid polypeptide (IAPP) is amyloidogenic. Transgenic mice overexpressing human IAPP in the $\beta$ cells of the islets of Langerhans should be useful in identifying factors important for the deposition of IAPP as insoluble amyloid fibrils.

Materials and Methods: Transgenic mice expressing human IAPP were examined using several experimental models for the production of persistent hyperglycemia, as well as for the overstimulation and/or inhibition of $\beta$ cell secretion. Obesity was induced by aurothioglucose. Persistent hyperglycemia was produced by long-term administration of glucocorticosteroids or by partial pancreatectomy. Inhibition of normal $\beta$ cell exocytosis by diazoxide administration, with or without concurrent dexamethasone injections, was carried out to increase crinophagy of secretory granules. The human IAPP gene was also introduced into the $d b$ and $o b$ mouse models for
\end{abstract}

diabetes. Finally, isolated islets cultivated in vitro at high glucose concentration were also examined.

Results: No amyloid deposits were found in the pancreata of any of the animals, either by light microscopy after Congo red staining or by electron microscopy after immunogold labeling with antibodies specific for human IAPP. Aurothioglucose treatment resulted in increased numbers of granules in the $\beta$ cell and the appearance of large lysosomal bodies without amyloid. However, islets from $d b$ and $o b$ mice expressing human IAPP cultivated in vitro in the presence of glucocorticosteroid and/or growth hormone, were found to contain extracellular amyloid deposits reacting with antibodies to human IAPP. Conclusions: Oversecretion of human IAPP or increased crinophagy are not sufficient for amyloid formation. This indicates that other factors must influence amyloid deposition; one such factor may be the local clearance of IAPP.

\section{INTRODUCTION}

Islet amyloid polypeptide (IAPP) was purified first from an amyloid containing insulinoma (1) and later from the amyloid deposits found in the

Address correspondence and reprint requests to: Gunilla Westermark, Department of Pathology, University Hospital, S-58185 Linköping, Sweden. islets of Langerhans in association with spontaneous diabetes in the cat and with human type 2 diabetes $(2,3)$. IAPP has been localized by immunohistochemistry to the $\boldsymbol{\beta}$ cells of the pancreas, where it is synthesized and stored with insulin in secretory granules $(4-6)$. The levels of IAPP in the pancreas and in the circulation are about $2 \%$ of the levels of insulin (7). Human IAPP is syn- 
thesized as an 89 amino acid pre-propeptide $(8,9)$. ProIAPP is post-translationally processed by removal of the relatively short $\mathrm{C}$ - and $\mathrm{N}$ terminal flanking regions. These cleavages occur at dibasic amino acid pairs similar to those found in other prohormones and the biologically active IAPP is C-terminally amidated.

IAPP is most similar in amino acid sequence, overall length, and disulfide bond structure to the calcitonin gene-related peptide (CGRP), a neuroendocrine peptide expressed in the brain and peripheral nervous system. Although the function(s) of IAPP is not well understood, some experiments have shown that high doses cause insulin resistance, acting largely at the level of the skeletal muscle, where it decreases glycogen synthesis (10), and possibly in the liver by activating glycogen phosphorylase (11). Studies of auto- or paracrine effects of IAPP on the islet $\beta$ cell have yielded conflicting results. Both inhibition of glucose-stimulated insulin release and increased release of insulin in response to glucose have been reported, depending on the dosage of IAPP administered (12), the experimental conditions, and possibly the quality of the IAPP preparation used. Although high-affinity binding of IAPP has been found in the brain and some other tissues $(13,14)$, a specific IAPP receptor protein has not yet been identified.

Islet amyloid deposits are present in a high percentage of type 2 diabetic patients and, to a minor extent, in older nondiabetic adults $(15,16)$. The amount of amyloid deposited varies, sometimes affecting only a few islets, while in other cases, it replaces the major part of the endocrine tissues of the pancreas (17). The role (if any) for IAPP in the pathogenesis of type 2 diabetes is not established, but the strong association of amyloid deposits in the islets of individuals with type 2 diabetes suggests that it could be a contributing factor. The amyloidogenic properties of the human IAPP molecule seem to be dependent on the amino acid sequence GAILS, at positions $24-28$ of the mature molecule (18). This sequence has also been found in other species, including cat $(19,20)$, raccoon $(21)$, monkey (22), and dog (22), where IAPP-derived amyloid has been shown to occur in conjunction with conditions resembling human type 2 diabetes or, as in the $d o g$, in association with insulinomas (23). In the monkey, a similar sequence, GTILS, is also amyloidogenic (22). Rodents, including mouse, rat (20), and hamster (24), which are the most commonly used animals in experimental diabetes research, have IAPP molecules that dif- fer in sequence in this region and do not form $\beta$ sheet fibrils in vitro (18). IAPP-derived amyloid has not been found in any of these species. Therefore, transgenic mice (over)expressing the human IAPP gene, might provide a useful model for studying the mechanisms leading to amyloid deposition in the islets and the possible role of islet amyloid in the pathogenesis of diabetes. They might also offer insights into unresolved issues, such as to where and why islet amyloid deposits are first formed (for example, is amyloid formation an extracellular event or are amyloid fibrils first formed within the $\beta$ cell and then released into the surrounding extracellular space?).

\section{MATERIAL AND METHODS}

\section{Animals}

The transgenic hIAPP mouse strain used in this work (L16) has been described elsewhere (25). It was one of several strains that were produced utilizing a transgene containing a 523-bp segment of the rat insulin 1 gene promoter fused to a 7.7-kb genomic DNA fragment containing the full-length human IAPP gene. In these mice, human IAPP is expressed mainly in the $\beta$ cells of the pancreas, while smaller amounts of IAPP mRNA can also be detected in the brain and anterior pituitary (25). The plasma levels of IAPP (total) are increased 3- to 5-fold. No alteration of fasting insulin or glucose levels have been observed in these animals when compared with nontransgenic $(\mathrm{FVB} / \mathrm{N})$ litter mates. No spontaneously formed amyloid deposits were found in the islets of these transgenic animals at the age of 1 year.

The presence of the human IAPP gene was demonstrated in animals selected for these studies by dot-blot analysis using a human-specific IAPP probe on DNA extracted from the tail of 2-week-old mice, and was verified by immunohistochemical staining with an antiserum specific for human IAPP20-29 (A133) (see below) on pancreas sections after each animal was sacrificed. Plasma glucose levels were measured with a Beckman Glucose Analyzer 2 (Beckman, Palo Alto, CA, U.S.A.) on blood obtained from the orbital sinus. During the experiments, the animals were maintained on a standard 12-hr light cycle and fed standard chow pellets and water ad libitum. 


\section{Pancreatic Tissue}

The pancreata from all animals were examined for the presence of amyloid by both light and electron microscopy. For light microscopy, pancreatic tissue was fixed in $10 \%$ neutral buffered formalin (NBF) and embedded in paraffin. Ten micron-thick sections were stained for amyloid with Congo red and viewed under polarized light (26). Tissue samples for electron microscopy were cut into $0.5-\mathrm{mm}$ cubes, fixed in $2.5 \%$ glutaraldehyde in $0.1 \mathrm{M}$ phosphate buffer, $\mathrm{pH} 7.4$, and thereafter embedded in Epon (Agar Aids Ltd., Stanstead, Essex, United Kingdom), polymerized at $+60^{\circ} \mathrm{C}$ or Lowicryl K4M (Polysciences, Eppelheim, Germany), photopolymerized at $-20^{\circ} \mathrm{C}$.

\section{Antisera}

A polyclonal antiserum (A110) was raised in a rabbit against a synthetic peptide corresponding to the mature rat/mouse IAPP 1-37. This antiserum cross-reacts well with IAPPs of various species, including human. Specific antiserum to human IAPP (A133) was raised in a rabbit against a decapeptide corresponding to positions 20-29 of the mature human IAPP molecule. This antiserum detects human IAPP but does not react with mouse IAPP. The IAPP antisera were used in dilution 1:400-1:800 for light microscopy and 1:200 for electron microscopy. Insulin antibodies (Dakopatts, Glostrup, Denmark), made in guinea pig, were used in dilution 1:400. Somatostatin antibodies (Dakopatts, Glostrup, Denmark), made in rabbit, were used in dilution 1:1000 (electron microscopy only).

\section{Immunohistochemistry and Immune- Electron Microscopy}

For light microscopy, 4 micron thick deparaffinized sections were incubated with IAPP antibodies overnight at room temperature. The primary antibodies was detected with a biotinylated porcine anti-rabbit antibodies followed by a streptavidin peroxidase complex (Dakopatts, Glostrup, Denmark). The insulin antibodies were detected with peroxidase conjugated rabbit antiguinea pig antibodies. The reactions were visualized with 3,3'-diaminobenzidine. For controls, the primary antiserum was replaced with rabbit nonimmune serum.

For electron microscopy, ultrathin sections were placed on nickel grids and incubated with primary antibodies diluted in $0.1 \mathrm{M}$ Tris $\mathrm{HCl}$ buffer, $\mathrm{pH} 7.6$, containing $0.15 \mathrm{M} \mathrm{NaCl}-1 \%$ bovine serum albumin, overnight at room temperature. The primary antibody was detected with a secondary antibody conjugated with $10 \mathrm{~nm}$ gold particles (Biocell, Cardiff, United Kingdom). The sections were counterstained in uranyl acetate and lead citrate and viewed in a Jeol 1200 electron microscope.

\section{Pancreatectomy}

Subtotal pancreatectomy was performed on 11 IAPP-transgenic and eight nontransgenic male mice (age 8-12 weeks). The animals were anesthetized with an intraperitoneal injection of chloralhydrate $(12 \mathrm{mg})$. The major part of the splenic and gastric pancreas was removed, together with the spleen, leaving a minor part of the pancreatic caput containing the pancreatic duct. Blood glucose levels of these animals were followed and the animals were sacrificed after 7 months.

The mean islet areas were determined on IAPP-immunolabeled pancreatic sections with the aid of computerized morphometric analysis (Lab Eye, Innovativ Vision, Linköping, Sweden). For each animal sections of 10 different islets were chosen arbitrarily and the mean islet area was calculated.

\section{Induction of Obesity}

To induce obesity (27), aurothioglucose (Sigma) (30 mg/ml in $0.15 \mathrm{M} \mathrm{NaCl}$ ) was given as a single intraperitoneal injection. Four hIAPP-transgenic females were given $300 \mathrm{mg} / \mathrm{kg}$ and 11 hIAPPtransgenic females and 5 nontransgenic litter mates were given $500 \mathrm{mg} / \mathrm{kg}$. Eleven nontreated females (five transgenic and six nontransgenic) were used as weight controls. All animals were 8-12 weeks old. The body weight was followed and all the animals were sacrificed after 6 months. The blood glucose concentrations were not followed in these animals.

\section{Cortisone Acetate Treatment}

Eleven transgenic males and 10 nontransgenic litter mates (age 8-12 weeks) were given 0.20 mg cortisone acetate as a daily injection subcutaneously in the suprascapular region. These animals were sacrificed after three different time intervals: 60 days after a total dose of $12 \mathrm{mg}$ steroid; 170 days after a total dose of $34 \mathrm{mg}$ 
steroid; or 205 days after a total dose of $41 \mathrm{mg}$ steroid. Blood glucose levels were followed.

\section{Diazoxide Treatment}

Diazoxide $(28,29)$ ( $0.8 \mathrm{mg}$ daily) was administered subcutaneously for 5 days to four animals, and the animals were then sacrificed. In a second experiment, dexamethasone $(0.125 \mathrm{mg} / \mathrm{kg})$ was given twice a day for 4 days prior to daily injections of diazoxide ( $1 \mathrm{mg}$ given twice a day) over a period of 23 days to five animals. One group of treated animals was sacrificed immediately, while another two animals were maintained for an additional 50 days without further injections before sacrifice. Only 8- to 12-week-old hIAPP transgenic females were used in this experiment.

\section{Crossbreeding of IAPP Transgenic Mice}

Human-IAPP-positive males were mated with heterozygous carriers of a diabetic gene, either $o b / \mathrm{m}+$ (30) or $d b / \mathrm{m}+$ (31) females. The light brown hIAPP-positive offspring in the first generation were used for further breeding. The offspring in the second generation had either white coat color as the original IAPP transgenic mice or dark brown coat color as the $o b / \mathrm{m}+$ or $d b / \mathrm{m}+$ females. The dark brown hIAPP-positive animals were used for further breeding. The pancreata from 17 obese hIAPP/ob and nine obese hIAPP/ $d b$ animals, age 4-12 months, were fixed in $10 \% \mathrm{NBF}$ and stained for amyloid with Congo red. Pancreatic tissue was also fixed in $2.5 \%$ glutaraldehyde in phosphate buffer and studied by electron microscopy after immunogold labeling with specific IAPP antibodies, as described above.

\section{Isolation and Cultivation of Islets}

Pancreatic islets were isolated from three hIAPP transgenic mice, three obese hIAPP/ $d b$ mice, and three obese hIAPP/ob mice. The pancreas was removed from anesthetized animals and cut into small pieces. This material was digested with collagenase $\mathbf{P}$ (Boehringer-Mannheim, Indianapolis, IL) $(3 \mathrm{mg} / \mathrm{ml})$ in Hank's balanced salt solution (Gibco-BRL, Gaithersburg, MD, U.S.A.) for 10 min at $37^{\circ} \mathrm{C}$ under constant shaking. Islets were recovered after separation on a Ficoll 400-DL (Sigma Chemical Co., St. Louis, MO, U.S.A.) gradient (32). Isolated islets were cultured in RPMI1640 medium containing $15 \%$ fetal calf serum and $16.5 \mathrm{mM}$ glucose. In some of the cultures,
$0.5 \mathrm{mM}$ dexamethasone (Sigma) or $10 \mu \mathrm{g} / \mathrm{ml}$ growth hormone (Sigma), or both, were added. After 7 days in culture, nonattached islets (five to six islets from each of the 12 different batches) were harvested, rinsed in $0.15 \mathrm{M}$ phosphate buffer, $\mathrm{pH} 7.4$, containing $0.15 \mathrm{M} \mathrm{NaCl}$, and fixed in $2.5 \%$ glutaraldehyde in phosphate buffer for 1 $\mathrm{hr}$ at room temperature, and thereafter were embedded in Lowicryl. Ultrathin sections were labeled with antisera as described above and studied by electron microscopy.

\section{Statistical Methods}

Values are presented as mean \pm SEM. Comparisons among groups of mice were made using repeated measures analysis of variance (ANOVA) followed by Tukey-Kramer multiple comparisons test. Comparisons of results between groups was assessed by the Mann-Whitney $U$ test or the Student's $t$ test. A $p$ value of $<0.05$ was considered statistically significant.

\section{RESULTS}

\section{Immunohistochemistry and Electron Microscopy of Untreated Animals}

As expected, human-specific IAPP antiserum A133 labeled islets in transgenic animals while islets of nontransgenic litter mates were unlabeled. The islets of the transgenic animals showed a somewhat irregular staining intensity. At the electron microscopic level with antiserum Al10, gold particles appeared on $\beta$ - and $\delta$-cell granules in both transgenic and non-transgenic animals, while antiserum Al33 labeled only $\beta$-cell granules in transgenic animals (Fig. 1 A-C). With antiserum Al 10, the labeling of the $\partial$ cells was as intense as the labeling of the $\beta$ cells.

\section{Pancreatectomized Animals}

Two of 11 transgenic and three of eight control pancreatectomized mice died before the experiment was completed and pancreatic samples were not saved from them. When the remaining animals were sacrificed after 7 months, the nonfasting blood glucose concentration had increased in both nontransgenic (from $146 \pm 4$ $\mathrm{mg} / \mathrm{dl}$ to $234 \pm 19 \mathrm{mg} / \mathrm{dl} ; p<0.01$ ) and transgenic animals (from $146 \pm 3$ to $226 \pm 10 ; p<$ $0.001)$. No significant differences in blood glucose levels were evident between the transgenic 


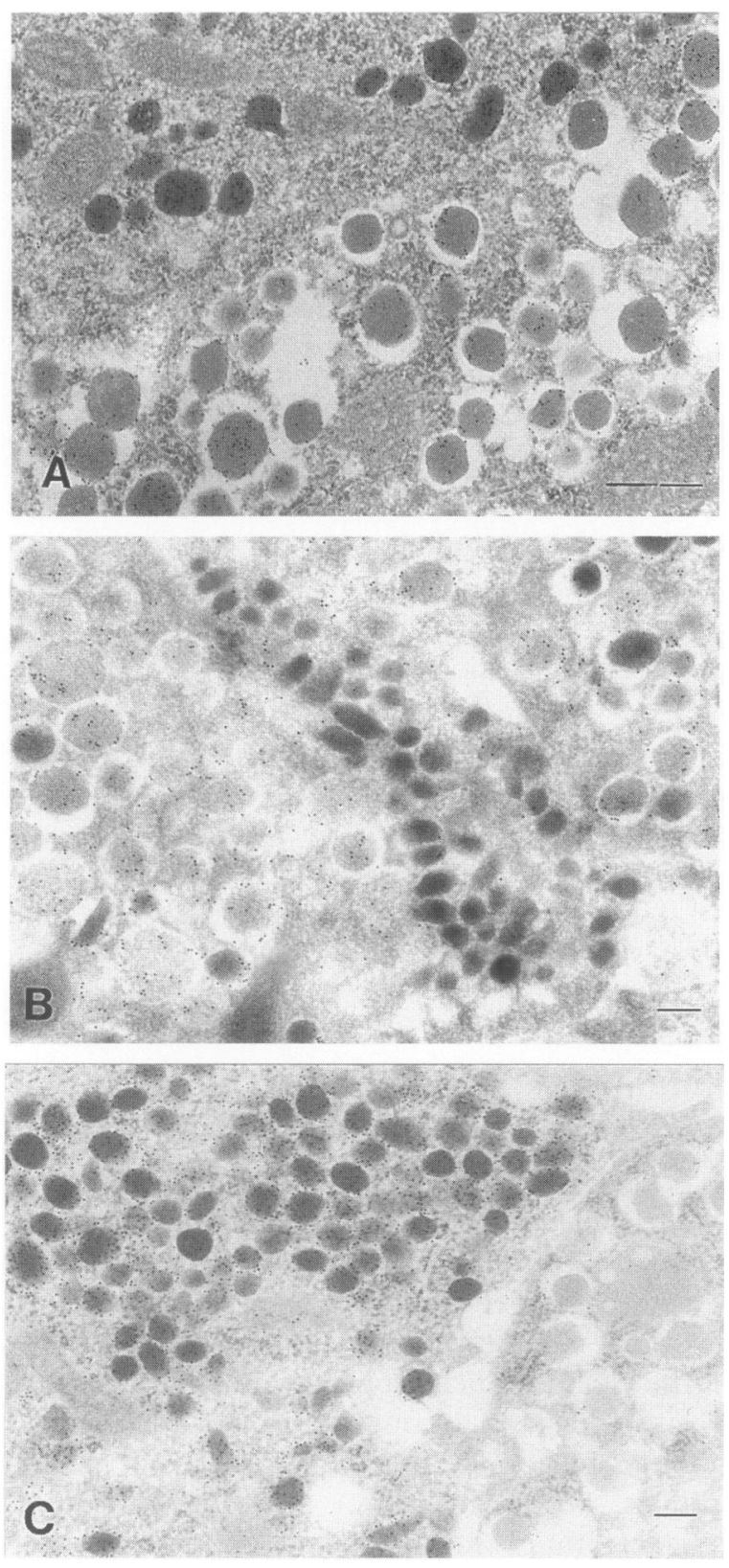

FIG. 1. Immunolabeling of untreated transgenic and nontransgenic mice

(A) Immunolabeling of $\beta$ and $\delta$ cell with antiserum against mouse IAPP. This pattern occurs in both transgenic and nontransgenic mice. Antiserum Al 10 l:200; $10 \mathrm{~nm}$ gold particles; bar $=500 \mathrm{~nm}$. (B) Immunolabeling of $\beta$ cells in a transgenic mouse with a human specific antiserum. No labeling occurs on the $\delta$ cell in the center of the figure. Antiserum Al33 1:200; $10 \mathrm{~nm}$ gold particles; bar $=200 \mathrm{~nm}$. (C) Immunolabeling of a $\delta$ cell with antiserum against somatostatin (1: 1000); $10 \mathrm{~nm}$ gold particles; bar $=200$.

and control mice. The islets were markedly enlarged in both transgenic and nontransgenic pancreatectomized animals compared with nonpancreatectomized litter mates $(3352 \pm 634$ and
$1161 \pm 108$ arbitrary units; $p=0.0018$ ). The immunostaining of islets in the pancreatectomized mice appeared weaker compared with those in nonpancreatectomized animals. This was true for both insulin and IAPP antisera and could be a result of degranulation of the $\beta$ cells in response to the higher blood glucose levels in the pancreatectomized mice.

\section{Obese Animals}

The minimal effective dose of aurothioglucose, reported to be $0.3 \mathrm{mg} / \mathrm{g}$ body weight, was given to four transgenic females. This dose did not cause a significant weight gain over a period of 6 months compared with nontreated animals $(3.4 \pm 2.0 \mathrm{~g}$ versus $4.6 \pm 0.8 \mathrm{~g})$. The transgenic animals that received $0.5 \mathrm{mg} / \mathrm{g}$ body weight of aurothioglucose showed a weight increase of 6.4 $\pm 2 \mathrm{~g}$, while the nontransgenic mice increased $9.1 \pm 3.0 \mathrm{~g}$. However, the animals in these two groups varied highly in weight gain, which was $12.3-21.4 \mathrm{~g}$ in three transgenic animals and 11.3 and $19.3 \mathrm{~g}$ in two nontransgenic animals. By both light and electron microscopy, the islets appeared normal in all aurothioglucose-treated animals. The immunogold labeling with the two IAPP antisera did not differ from nontreated transgenic and nontransgenic control animals.

\section{Glucocorticosteroid-Treated Animals}

Both transgenic and nontransgenic litter mates developed a severe and persistent hyperglycemia following cortisone acetate treatment. Blood glucose levels were significantly elevated by Day 60 in both groups (Table 1). Further increases in blood glucose levels occurred beyond Day 60 in both transgenic and nontransgenic animals, but were only significantly higher than the Day 60 level in the transgenics. Changes symptomatic of this hyperglycemic state and effects of the corticosteroid, such as anorexia and diarrhea, also developed in both groups. Severe adrenal atrophy and intraperitoneal fat depletion were notable at necropsy. Nevertheless, the light and electron microscopic findings in the pancreatic islets of the transgenic animals did not differ from those in control animals.

\section{Lack of Amyloid In Vivo}

Congo red-stained pancreatic sections from all animals discussed above were studied and no bonafida amyloid deposits were detected in the 
TABLE 1. Blood glucose concentration $\mathrm{mg} / 100$ $m$ (mean \pm SEM) in hIAPP transgenic and nontransgenic litter mates, before and during long-term treatment with glucocorticosteroid

\begin{tabular}{ccc}
\hline Day & $\begin{array}{c}\text { Transgenic } \\
\text { Mice }\end{array}$ & $\begin{array}{c}\text { Nontransgenic } \\
\text { Mice }\end{array}$ \\
\hline Fasting & & \\
0 & 67.1 & 73.6 \\
Fed & 2.4 & 4.1 \\
0 & $n=11$ & $n=10$ \\
& & 126.8 \\
60 & 117.2 & 4.5 \\
& 5.2 & $n=10$ \\
& $n=11$ & $214.8^{a}$ \\
130 & $206.4^{a}$ & 3.1 \\
& 4.5 & $n=10$ \\
& $n=11$ & $217.3^{b}$ \\
170 & $214.5^{b}$ & 3.8 \\
& 3.4 & $n=7$ \\
& $n=8$ & 222.1 \\
& $219.6^{b}$ & 4.7 \\
& 3.6 & $n=7$ \\
& $n=8$ & 221.8 \\
& 220.0 & 10.8 \\
& 6.0 & $n=4$ \\
\hline 0.001 & $n=4$ & \\
& & \\
& &
\end{tabular}

${ }^{a} p<0.001$ versus Day 0

${ }^{b} p<0.05$ versus Day 60 .

pancreata of any of the mice by light microscopy. Two islets from each animal were studied by electron microscopy immunogold labeling with IAPP specific antibodies and showed reactivity only within secretory granules in $\beta$ and $\partial$ cells. There was no IAPP immunoreactivity in lysosomes or in any amyloid-like material, either intracellularly or extracellularly, with either of the two antisera.

\section{Diazoxide-Treated Animals}

The inhibition of degranulation induced by diazoxide was evident as a significantly increased number of $\beta$-cell granules, which, in the transgenic animals, were heavily labeled with the two IAPP antisera (Fig. 2). Enlarged lysosomes and multivesicular bodies were also evident in the $\beta$ cells. When dexamethasone pretreatment was

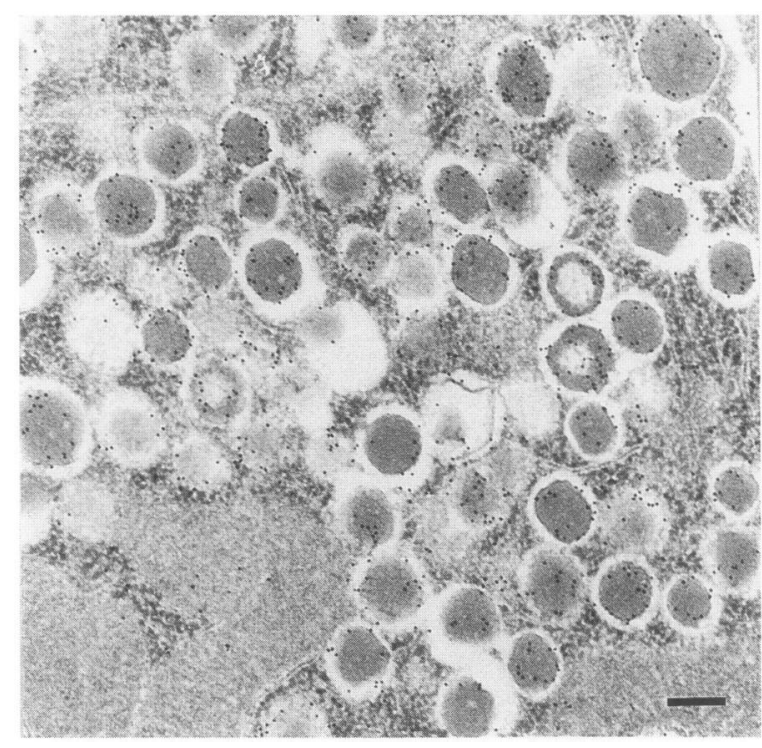

FIG. 2. $\beta$ cell from an islet of a hIAPP transgenic mouse, treated with diazoxide

Antiserum Al33 1:200; 10 nm gold particles; bar = $500 \mathrm{~nm}$.

added, an increase in IAPP immunoreactivity was evident in the $\beta$-cell granules, but no IAPP immunoreactivity could be detected in the lysosomes by electron microscopic immunocytochemistry. Small aggregates of IAPP immunolabeled amorphous material could sometimes be detected in perivascular areas. The aggregates were localized on the islet cell side of the basement membrane and in close association with the $\beta$ cells (Fig. 3). There was no evidence for amyloid fibrils in these depositions. In the animals allowed to recover and sacrificed 50 days after diazoxide administration was stopped, the islets were morphologically indistinguishable from normal mouse islets. No amyloid was found in any of the mice examined $(n=9)$.

\section{Crossbreeding Experiments}

The influence of diabetic syndromes on amyloid fibril formation was examined in diabetic transgenics developed by intercrossing $d b / \mathrm{m}+$ or $o b / \mathrm{m}+$ mice with hIAPP transgenics. Only transgenics homozygous for $d b$ or $o b$ (animals with the greatest potential of being affected) were studied. Obese diabetic hIAPP/ob mice $(n=17)$ were studied at 4-12 months of age. Obese diabetic hIAPP/db mice $(n=9)$ were studied at $4-5$ months of age, since studies in older animals 


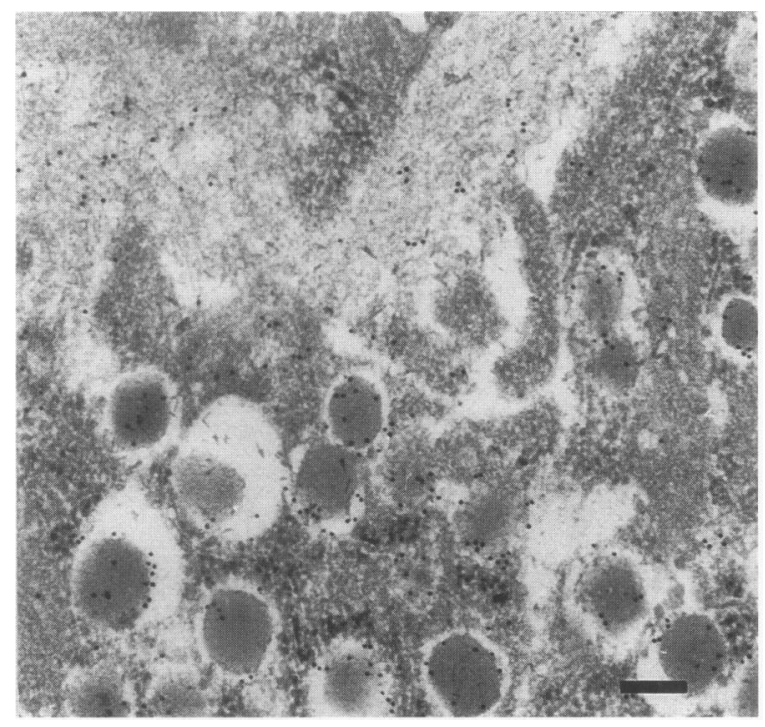

FIG. 3. Immunolabeling of a $\beta$ cell and nonfibrillar amorphous material in the islet of a hIAPP transgenic mouse treated with diazoxide

Antiserum Al33 1:200; $10 \mathrm{~nm}$ gold particles; bar = $200 \mathrm{~nm}$.

were precluded by the development of morbidity (no exogenous insulin was given to prolong the lives of these animals). Blood glucose levels were significantly elevated at the time of sacrifice in all animals studied $(477 \pm 18 \mathrm{mg} / \mathrm{dl}$ for hIAPP/ob mice and $486 \pm 23 \mathrm{mg} / \mathrm{dl}$ for hIAPP/db mice). The hIAPP/ $o b$ and hIAPP/ $d b$ mice developed the same morphological islet changes as those described for nontransgenic homozygous $o b$ and $d b$ mice $(30,31)$. Thus, the hIAPP/ob mice had an increased number of large islets, mainly due to $\beta$-cell proliferation. In hIAPP/ $d b$ mice, the clear demarcation zone between exocrine and endocrine pancreatic tissue was disrupted by ingrowth of exocrine tissue into the islets and the $\beta$ cells were degranulated. No Congo red-positive material was found in the islets of any of these animals. The large vascularized islets seen in the hIAPP/ob mice showed strong IAPP reactivity after staining with human specific IAPP antiserum (A133) (Fig. 4) or with antiserum to mouse IAPP (A110). The intensity in immunoreactivity in $\beta$ cells in obese hIAPP/ $d b$ mice varied between the two antisera and also differed between islets in the same pancreas (Fig. 5). No amyloid fibrillar material could be found at the electron microscopic level in any of the animals (two islets

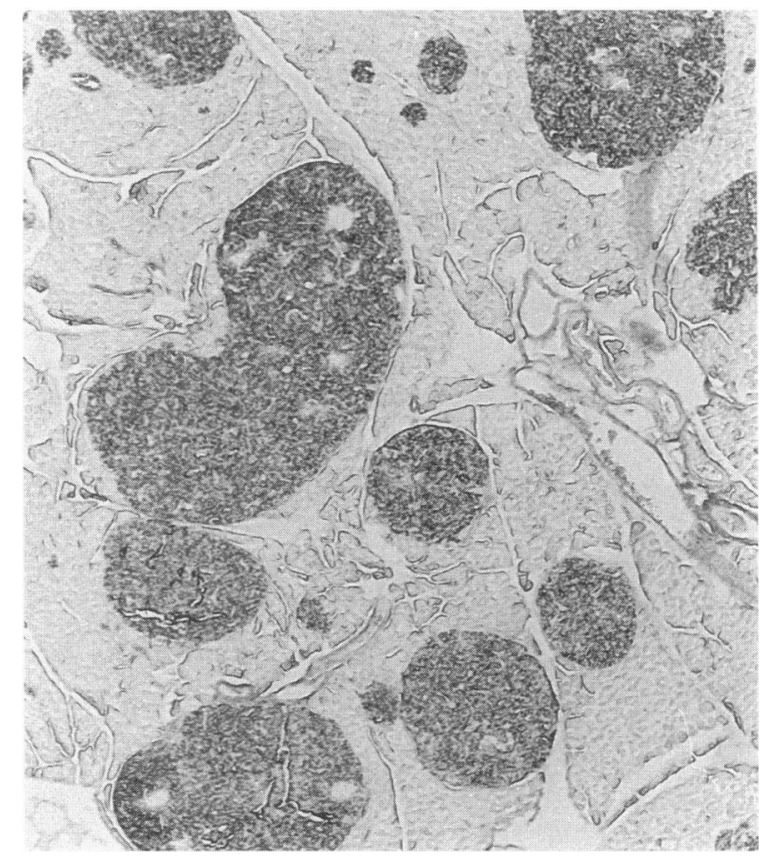

FIG. 4. Immunohistochemistry of enlarged vascularized islets from an $o b /$ hIAPP transgenic mouse

H-IAPP specific antiserum Al33 1:800; 45×.

studied in each of $17 o b /$ hIAPP and nine $d b /$ hIAPP mice).

\section{In Vitro Cultured Islets}

Since unknown host factors may have prevented the development of amyloid in vivo in the above experiments, the amyloidogenic potential in transgenic islets was examined in vitro. No histological differences were found between islets cultured in medium with only high glucose concentration and those cultured with the addition of growth hormone and/or dexamethasone for 7 days. In the L-16 transgenic mouse islets, the reactivity with the A133 antiserum was limited to the $\beta$-cell granules and no reactivity was found elsewhere intracellularly. Small deposits of extracellular amyloid fibrils were found in all six batches of cultured islets from the hIAPP/ob (Fig. 6) and hIAPP/db mice that had been cultivated in the presence of dexamethasone and/or growth hormone (Fig. 7). The amyloid was mainly found in association with the plasma membrane of degenerating or dead $\beta$ cells. The fibrils reacted strongly with both IAPP-antisera, confirming the presence of hIAPP. 


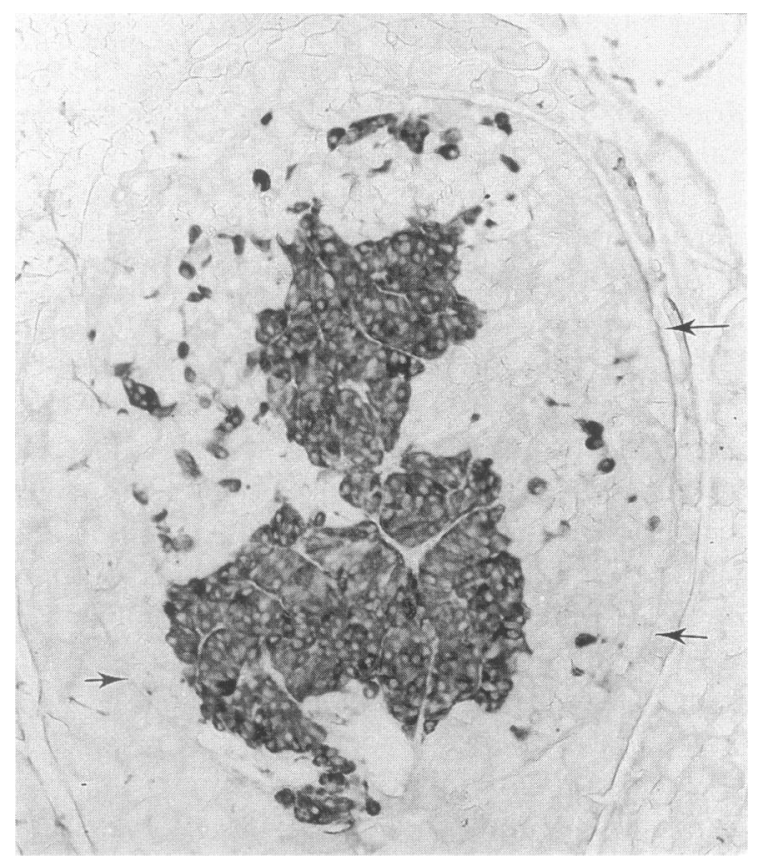

FIG. 5. Immunohistochemistry of cellular remains of an islet from a $d b / h I A P P$ transgenic mouse

Arrow points to the former location of the outer rim of the islet. Note exocrine pancreatic proliferation into the islet. H-IAPP specific antiserum Al33 1:800; $120 \times$.

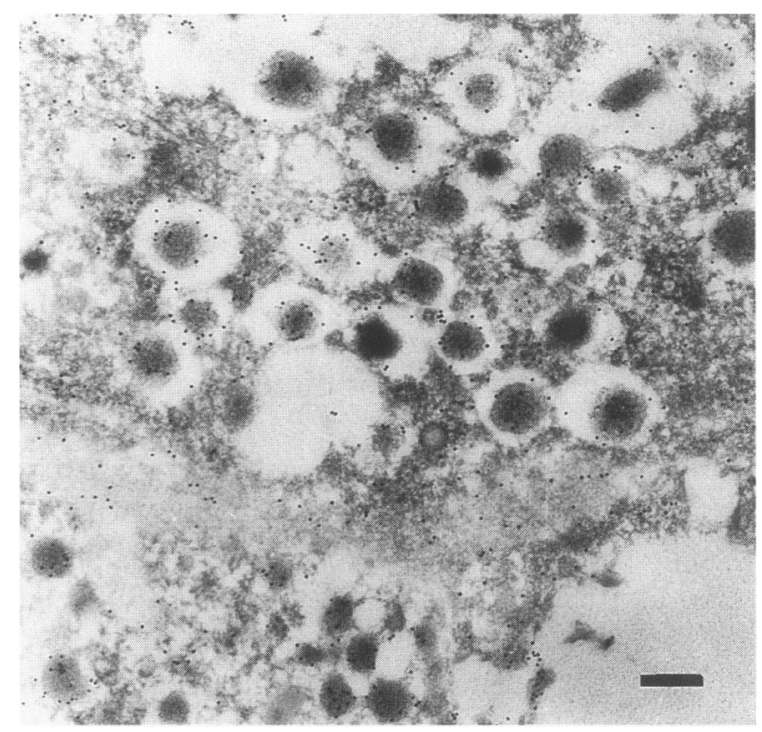

FIG. 7. Amyloid deposited between two $\beta$ cells in an isolated and in vitro incubated islet from an $o b / h I A P P$ transgenic mouse

Note IAPP-reactivity of amyloid fibrils and $\beta$-cell granules. Antiserum A133 1:200; 10 nm gold particles; bar $=200 \mathrm{~nm}$.
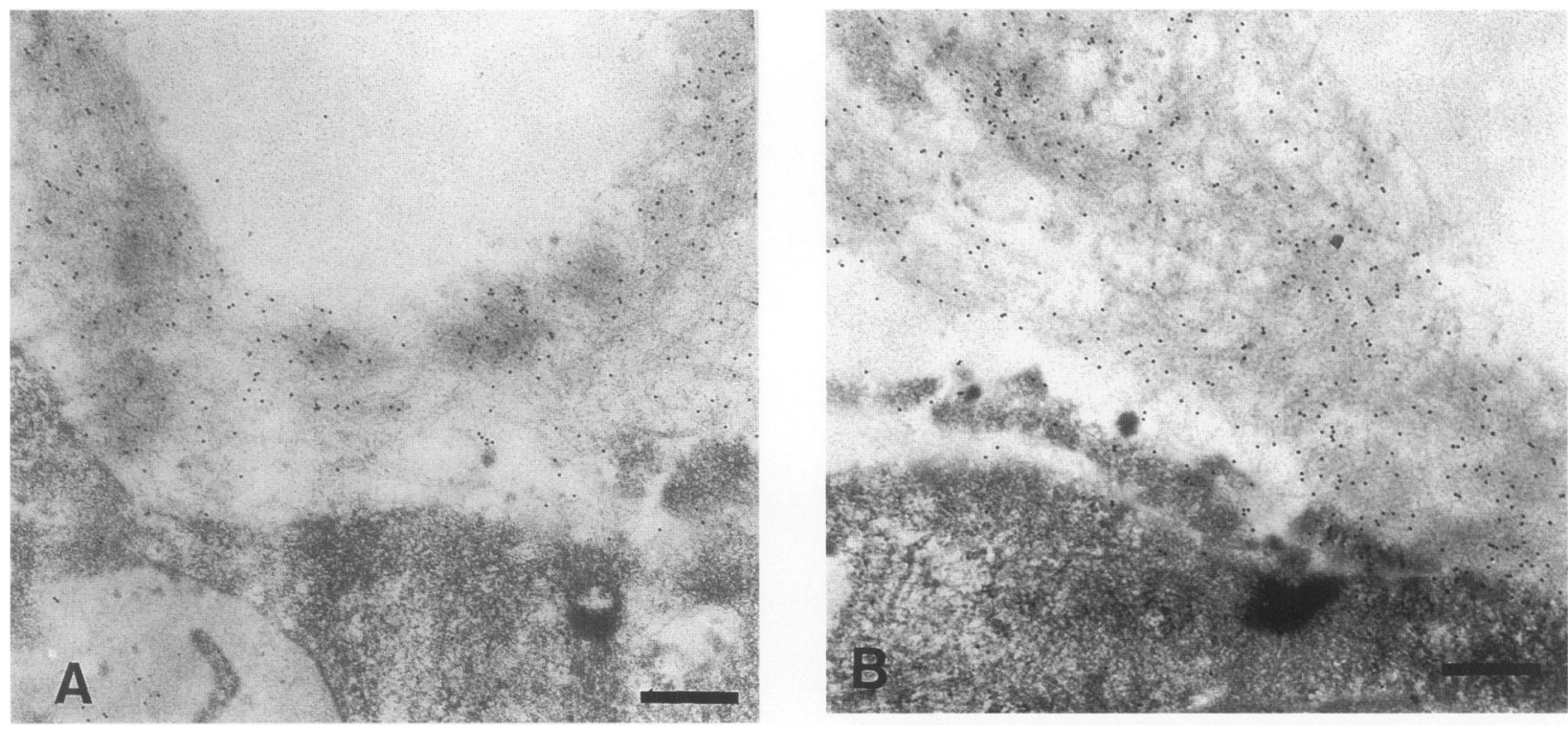

FIG. 6. Extracellular amyloid fibrils labeled with antiserum specific for human IAPP

(A and B) Isolated and in vitro incubated islet from an ob/hIAPP transgenic mouse. Antiserum Al33 1:200; $10 \mathrm{~nm}$ gold particles; bar $=500 \mathrm{~nm}$. 


\section{DISCUSSION}

In order to study islet amyloid formation, several different groups of investigators have created transgenic mice expressing human IAPP in their islets $\beta$ cells $(25,33,34)$. Despite successful expression of the human IAPP gene in the $\beta$ cells and resulting overproduction of IAPP, there have been no reports of the formation of typical islet amyloid deposits in any of these animal lines in vivo.

In humans, islet amyloid formation is clearly associated with type 2 diabetes $(15,17,35)$. Although the nature of this association has not been clarified, two factors are believed to be of importance: namely, the presence of an amyloidogenic IAPP sequence and high levels of IAPP expression (18-22). We, therefore, wanted to study the effects of " $\beta$-cell stress" on the possible formation of islet amyloid in mice expressing human IAPP. The increase in stress was achieved both directly, by removing $70 \%$ of the splenic and gastric pancreas, and indirectly, by treatment with glucocorticosteroids and by inducing hyperphagia and obesity. In spite of these manipulations, no amyloid deposits appeared in relatively long-term experiments, indicating that additional factors are probably necessary for islet amyloid formation in type 2 diabetes.

An interesting finding of the glucocorticosteroid treatment experiment, where blood glucose concentrations were followed at several time intervals, was that the hIAPP transgenic mice invariably had slightly lower values than the nontransgenic litter mates (Table 1). Although these differences were not statistically significant, these data do not support the theory of a hyperglycemic effect of high IAPP plasma values (36).

In human pancreas, the smallest and, therefore, probably the earliest amyloid deposits are found extracellularly, in close proximity to the $\beta$ cells (35), suggesting that the initiation of fibril formation occurs extracellularly (37). There is, however, evidence of intralysosomal formation of amyloid fibrils in experimental AA amyloidosis (38), and it has been proposed that islet amyloid formation may also take place intracellularly as a consequence of increased crinophagy (39). In our experiments, inhibition of granule release by diazoxide administration was used to enhance intracellular granule retention and subsequent degradation via crinophagy. Although large aggregations of granule-containing lysosomal complexes were found in the $\beta$ cells of the diazoxide-treated transgenic mice, no amyloid could be demonstrated either extra- or intracellularly. hIAPP-Positive extracellular material was observed, but it lacked the characteristic fibrillar appearance of amyloid.

The $d b / d b$ and $o b / o b$ mice are experimental mouse models of diabetes resembling diabetic syndromes in man and are both inherited as an autosomal recessive trait. In the $o b / o b$ mice hyperinsulinemia is stimulated by hyperphagia and causes massive early-onset obesity. Insulin resistance occurs after prolonged hyperinsulinemia and involves both receptor and postreceptor defects. Increased numbers of enlarged islets filled with $\beta$ cells can be seen histologically. The $d b / d b$ mouse exhibits metabolic disturbances that resemble maturity onset diabetes mellitus in humans. The plasma insulin levels increase at an early age in association with hyperphagia, but later decline, and after 12 weeks, they are lower than those found in lean siblings. The $d b / d b$ mouse is initially obese, but the decrease in insulin production causes weight loss as diabetes supravenes in older animals. There is no histological evidence of islet cell regeneration in the $d b / d b$ mouse (40). The border between acinar tissue and islets is indistinct and the $\beta$ cells are degranulated. Because multiple factors are involved in the development of hyperphagia, obesity, and diabetes in these animal models, it was thought that the introduction of the human IAPP gene might indicate which factors lead to amyloid fibril formation. However, as in other in vivo experiments, amyloid was not detected at any time in the islets. Taken together, these experiments clearly indicate that the islet amyloid formation is not simply a consequence of a diabetic state or of IAPP overproduction.

We recently observed that isolated human islets transplanted under the kidney capsules of nude mice rapidly develop islet amyloid at high frequency, in both normoglycemic and hyperglycemic animals (41). We therefore wanted to determine whether isolation of hIAPP transgenic islets from their normal milieu might trigger amyloid formation. Very interestingly, islets from $o b / o b$ and $d b / d b$ transgenic mice cultured in vitro at high glucose concentration and in the presence of glucocorticosteroid and/or growth hormone developed small hIAPP-positive amyloid deposits extracellularly. Similar findings were also recently reported by de Koning et al. (42) using islets from hIAPP transgenic mice cultured in vitro for 7 days at high glucose concentration. Thus, in both transplanted isolated normal human islets and in vitro cultivated hIAPP 
transgenic mouse islets, amyloid formation occurs only when the islets have been removed from their normal surroundings and circulation. At present, it is only possible to speculate about the mechanisms leading to amyloidogenesis under these conditions. It is possible that abolishing the blood supply is an important factor, which leads to diminished clearance of released IAPP. Novials et al. (43) also found increased contents of IAPP in in vitro cultivated islets, although they were not examined for amyloid formation. Furthermore, besides the main fibril protein, amyloid deposits consistently contain minor components, such as amyloid P-component and heparan sulphate proteoglycan (44). Although the importance of these minor components in the formation of amyloid fibrils is poorly understood, it is possible that they facilitate fibril formation by acting as "pathological chaperones" (45). Changes in the synthesis and metabolism of such components may take place in association with amyloidogenesis.

The finding that the amyloid deposits occurred in close association with degenerating or dead islet cells might also be important. It has recently been shown that synthetic amyloid-like IAPP fibrils are toxic to $\beta$ cells in vitro, and a cytopathic role for amyloid deposits has been proposed (46). Further studies will be necessary to clarify the relationship between various factors in the pathogenesis of diabetes.

\section{ACKNOWLEDGMENTS}

This work was supported by the Swedish Medical Research Council (Project No. 5941), the Swedish Diabetes Association, the Novo-Nordisk Insulin Fund, National Institutes of Health Grants DK13914 and DK20595 and the Howard Hughes Medical Institute.

\section{REFERENCES}

1. Westermark P, Wernstedt C, Wilander E, Sletten K. (1986) A novel peptide in the calcitonin gene related peptide family as an amyloid fibril protein in the endocrine pancreas. Biochem. Biophys. Res. Commun. 140: 827-831.

2. Westermark $P$, Wernstedt $C$, Wilander E, Hayden DW, O'Brien TD, Johnson KH. (1987) Amyloid fibrils in human insulinomia and islets of Langerhans of the diabetic cat are derived from a neuropeptide-like protein also present in normal islet cells. Proc. Natl. Acad. Sci. U.S.A. 84: 3881-3885.

3. Cooper GJ, Willis AC, Clark A, Turner AC, Sim RB, Reid KBM. (1987) Purification and characterization of a peptide from amyloidrich pancreases of type 2 diabetic patients. Proc. Natl. Acad. Sci. U.S.A. 84: 8628-8632.

4. Johnson $\mathrm{KH}, \mathrm{O}^{\prime}$ Brien TD, Hayden DW, et al. (1988) Immunolocalization of islet amyloid polypeptide (IAPP) in pancreatic Beta cells by means of peroxidase-antiperoxidase (PAP) and protein A-gold techniques. Am. J. Pathol. 130: 1-8.

5. Clark A, Edwards CA, Ostle LR, et al. (1989) Localisation of islet amyloid peptide in lipofuscin bodies and secretory granules of human $\beta$-cells and in islets of type- 2 diabetic subjects. Cell Tissue Res. 257: 179-185.

6. Lukinius A, Wilander E, Westermark GT, Engström U, Westermark P. (1989) Co-localization of islet amyloid polypeptide and insulin in the B cell secretory granules of the human pancreatic islets. Diabetologia 32: 240-244.

7. Nagamatsu S, Nishi M, Steiner DF. (1991) Biosynthesis of islet amyloid polypeptide-elevated expression in mouse beta-TC 3 cells. $J$. Biol. Chem. 266: 13737-13741.

8. Sanke T, Bell GI, Sample C, Rubenstein AH, Steiner DF. (1988) An islet amyloid peptide is derived from an 89-amino acid precursor by proteolytic processing. J. Biol. Chem. 263: 17243-17246.

9. Betsholtz C, Svensson V, Rorsman F, et al. (1989) Islet amyloid polypeptide (IAPP): cDNA cloning and identification of an amyloidogenic region associated with speciesspecific occurrence of age-related diabetes mellitus. Exp. Cell Res. 183: 484-493.

10. Cooper GJS, Leighton B, Dimitriadis GD, et al. (1988) Amylin found in amyloid deposits in human type 2 diabetes mellitus may be a hormone that regulates glycogen metabolism in skeletal muscle. Proc. Natl. Acad. Sci. U.S.A. 85: 7763-7767.

11. Roden M, Liener K, Fürnsinn C, et al. (1992) Effects of islet amyloid polypeptide on hepatic insulin resistance and glucose production in the isolated perfused rat liver. Diabetologia 35: 116-120.

12. Westermark $\mathrm{P}$, Johnson $\mathrm{KH}, \mathrm{O}^{\prime}$ Brien TD, Betsholtz C. (1992) Islet amyloid polypeptide-A novel controversy in diabetes research. Diabetologia 35: 297-303. 
13. Beaumont K, Kenney MA, Young AA, Rank TJ. (1993) High affinity amylin binding sites in rat brain. Mol. Pharmacol. 44: 493-497.

14. Bhogal R, Purkiss P, Bloom SR. (1993) Molecular identification of binding sites for calcitonin gene-related peptide (CGRP) and islet amyloid polypeptide (IAPP) in mammalian lung-Species variation and binding of truncated CGRP and IAPP. Endocrinology 133: 2351-2361.

15. Bell ET. (1952) Hyalinization of the islets of Langerhans in diabetes mellitus. Diabetes 1: 341-344.

16. Bell ET. (1959) Hyalinization of the islets of Langerhans in nondiabetic individuals. $\mathrm{Am}$. J. Pathol. 35: 801-805.

17. Westermark P, Grimelius L. (1973) The pancreatic islet cells in insular amyloidosis in human diabetic and non-diabetic adults. Acta Path. Microbiol. Scand. A 81: 291-300.

18. Westermark $\mathrm{P}$, Engström U, Johnson $\mathrm{KH}$, Westermark GT, Betsholtz C. (1990) Islet amyloid polypeptide: pinpointing amino acid residues linked to amyloid fibril formation. Proc. Natl. Acad. Sci. U.S.A. 87: 50365040.

19. Betsholtz C, Christmanson L, Engström U, et al. (1990) Structure of cat islet amyloid polypeptide and identification of amino acid residues of potential significance for islet amyloid formation. Diabetes 39: 118-122.

20. Nishi M, Chan SJ, Nagamatsu S, Bell GI, Steiner DF. (1989) Conservation of the sequence of islet amyloid polypeptide in five mammals is consistent with its putative role as an islet hormone. Proc. Natl. Acad. Sci. U.S.A. 86: $5738-5742$.

21. Jordan KC, O'Brien TD, Johnson KH. (1994) Sequence of raccoon IAPP supports importance of a specific structural motif in the development of pancreatic islet amyloidosis. Amyloid 1: 160-164.

22. Ohagi S, Nishi M, Bell GI, Ensinck JW, Steiner DF. (1991) Sequences of islet amyloid polypeptide precursors of an old world monkey, the pig-tailed macaque (Macacanemestrina), and the dog (Canis-familiaris). Diabetologia 34: 555-558.

23. O'Brien TD, Westermark P, Johnson KH. (1990) Islet amyloid polypeptide and calcitonin gene-related peptide immunoreactivity in amyloid and tumor cells of canine pancreatic endocrine tumors. Vet. Pathol. 27: 194-198.

24. Nishi M, Bell GI, Steiner DF. (1990) Se- quence of a cDNA encoding Syrian hamster islet amyloid polypeptide precursor. Nucleic Acids Res. 18: 6726.

25. Fox N, Schrementi J, Nishi M, et al. (1993) Human islet amyloid polypeptide transgenic mice as a model of non-insulin-dependent diabetes mellitus (NIDDM). F.E.B.S. Lett. 323: 40-44.

26. Puchtler H, Sweat F, Levine M. (1962) On the binding of Congo red by amyloid. J. Histochem. Cytochem. 10: 355-364.

27. Drachman RH, Tepperman J. (1954) Aurothioglucose obesity in the mouse. Yale J. Biol. Med. 26: 394-408.

28. Creutzfeldt W, Creutzfeldt C, Frerichs H, Perings E, Sickinger K. (1969) The morphological substrate of the inhibition of insulin secretion by diazoxide. Horm. Metabol. Res. 1: 53-64.

29. Jansen GR, Hutchinson CF, Zanetti ME. (1967) Effects of diazoxide on glucose UC-14 utilization in mice. Diabetes 16: 777783.

30. Dubuc PU. (1976) The development of obesity, hyperinsulinemia and hyperglycemia in ob/ob mice. Metabolism 26: 1567-1574.

31. Coleman DL. (1978) Obesity and diabetes: Two mutant genes causing diabetes-obesity syndromes in mice. Diabetologia 14: 141-148.

32. Lernmark $\AA$, Nathans A, Steiner DF. (1976) Preparation and characterization of plasma membrane enriched fractions from rat pancreatic islets. J. Cell Biol. 71: 606-623.

33. Höppener JWM, Verbeek JS, de Koning EJP, et al. (1993) Chronic overproduction of islet amyloid polypeptide/amylin in transgenic mice: Lysosomal localization of human islet amyloid polypeptide and lack of marked hyperglycaemia or hyperinsulinaemia. Diabetologia 36: 1258-1265.

34. Verchere CB, D'Alessio DA, Palmiter RD, Kahn SE. (1994) Transgenic mice overproducing islet amyloid polypeptide have increased insulin storage and secretion in vitro. Diabetologia 37: 725-728.

35. Westermark P. (1973) Fine structure of islets of Langerhans in insular amyloidosis. Virchows Arch. A 359: 1-18.

36. Cooper GJS, Day AJ, Willis AC, Roberts AN, Reid KBM, Leighton B. (1989) Amylin and the amylin gene: Structure, function and relationship to islet amyloid and to diabetes mellitus. Biochim. Biophys. Acta 1014: 247258.

37. Westermark P. (1994) Amyloid and 
polypeptide hormones: What is their interrelationship? Amyloid 1: 47-60.

38. Shirahama T, Cohen AS. (1975) Intralysosomal formation of amyloid fibrils. Am. J. Pathol. 81: 101-116.

39. Clark A. (1992) Islet amyloid-An enigma of type-2 diabetes. Diab. Metabol. Rev. 8: 117132.

40. Coleman DL, Hummel KP. (1967) Studies with the mutation, diabetes, in the mouse. Diabetologia 3: 238-248.

41. Westermark P, Eizirik DL, Pipeleers DG, Hellerström C, Andersson A. (1995) Rapid deposition of amyloid in human islets transplanted into nude mice. Diabetologia 38: 543554.

42. de Koning EPJ, Morris ER, Hofhuis FMA, et al. (1994) Intra- and extracellular amyloid fibrils are formed in cultured pancreatic islets of transgenic mice expressing human islet amyloid polypeptide. Proc. Natl. Acad. Sci. U.S.A. 91: 8467-8471.

43. Novials A, Sarri Y, Casamitjana R, Rivera F, Gomis R. (1993) Regulation of islet amyloid polypeptide in human pancreatic islets. Diabetes 42: 1514-1519.

44. Young ID, Ailles L, Narindrasorasak S, Tan R, Kisilevsky R. (1992) Localization of the basement membrane heparan sulfate proteoglycan in islet amyloid deposits in type-II diabetes-mellitus. Arch. Pathol. Lab. Med. 116: 951-954.

45. Wisniewski T, Frangione B. (1992) Apolipoprotein E: A pathological chaperone protein in patients with cerebral and systemic amyloid. Neurosci. Lett. 135: 235-238.

46. Lorenzo A, Razzaboni B, Weir GC, Yankner BA. (1994) Pancreatic islet cell toxicity of amylin associated with type-2 diabetes mellitus. Nature 368: 756-760.

Contributed by D. F. Steiner on April 24, 1995. 